\title{
Comparative Study on Performances of Composite Anodes of SiO, Si and Graphite for Lithium Rechargeable Batteries
}

\author{
Chil-Hoon Doh, ${ }^{\dagger, *}$ Angathevar Veluchamy, ${ }^{\dagger, \star}$ Duck-Jun Lee,${ }^{\dagger}$ Jung-Hoon Lee, ${ }^{\dagger}$ Bong-Soo Jin, ${ }^{\dagger}$ Seong-In Moon, ${ }^{\dagger}$ \\ Cheol-Wan Park, ${ }^{\S}$ and Dong-Won Kim ${ }^{\#}$
}

\author{
${ }^{\dagger}$ Korea Electrotechnology Research Institute, Chang-won 641-600, Korea.*E-mail: chdoh@keri.re.kr \\ ${ }^{\ddagger}$ Central Electrochemical Research Institute, Karaikudi 630 006, India \\ ${ }^{\S}$ Sodiff Advanced Materials Co., Ltd., Yeongju 750-080, Korea \\ ${ }^{\#}$ Dept. Chem. Eng., CICM, Hanyang University, Seoul 133-791, Korea \\ Received August 17, 2009, Accepted March 9, 2010
}

\begin{abstract}
The electrochemical performances of anode composites comprising elemental silicon ( $\mathrm{Si}$ ), silicon monoxide ( $\mathrm{SiO}$ ), and graphite $(\mathrm{C})$ were investigated. The composite devoid of elemental silicon ( $\mathrm{SiO}: \mathrm{C}=1: 1$ ) and its carbon coated composite showed reduced capacity degradation with measured values of 606 and $584 \mathrm{mAh} / \mathrm{g}$ at the fiftieth cycle. The capacity retention nature when the composites were cycled followed the order of Si:SiO:C=3:1:4< Si:SiO:C 2:2:4 $<\mathrm{SiO}: \mathrm{C}=1: 1<\mathrm{SiO}: \mathrm{C}=1: 1$ (carbon coated). A comparison of the capacity retention properties for the composites in terms of the silicon content showed that a reduced silicon content increased the stability of the composite electrodes. Even though the carbon-coated composite delivered low capacity during cycling compared to the other composites, its low capacity degradation made the anode a better choice for lithium ion batteries.
\end{abstract}

Key Words: Silicon, Silicon monoxide, Graphite, Anode, Lithium ion battery

\section{Introduction}

Recently, the ability of silicon to form an alloy with lithium was explored to develop a high-capacity anode material for replacing graphite electrodes, which have low capacity ( $\sim 372$ $\mathrm{mAh} / \mathrm{g}$ ), for use in lithium ion batteries. ${ }^{1}$ Even though silicon in the intermetallic alloy $\mathrm{Li}_{22} \mathrm{Si}_{5}$ appears to possess a high theoretical specific capacity $4190 \mathrm{mAh} / \mathrm{g}$, its immediate practical application has been hampered because it exhibits large crystallographic volume changes of $\sim 328 \%$ during the charge/ discharge cycling process. ${ }^{2-5}$ However, methods such as the incorporation of metal powders into the composite ${ }^{6-9}$ and using silicon in alloys ${ }^{10,11}$ and compounds ${ }^{12}$ with graphite have been found to improve the electrode performance. Carbon coating of the composites has also been reported to provide high cycle stability to the anode. ${ }^{2,13-15}$

Among silicon-based composites, $\mathrm{SiO}$ shows better cycle performance than silicon composites; this is because during the initial lithiation process, the $\mathrm{Li}_{2} \mathrm{O}$ formed in situ acts as a buffer material, thereby preventing electrode degradation due to large volume changes. Along with $\mathrm{Li}_{2} \mathrm{O}, \mathrm{SiO}$ forms nanometric silicon, which alloys and de-alloys with lithium during the charge/discharge cycles. ${ }^{16,17}$ Thus, $\mathrm{Li}_{2} \mathrm{O}$ remains as an inert buffer material in the composite, which minimizes volume change during the cycling process. In contrast, for negative electrode materials made of nano-sized transition-metal oxides, Poizot et al. ${ }^{18}$ reported that the formation and decomposition of $\mathrm{Li}_{2} \mathrm{O}$ accompanies the reduction and oxidation of nanometric particles; they demonstrated a capacity value of $700 \mathrm{mAh} / \mathrm{g}$ with $100 \%$ capacity retention for up to 100 cycles with high rate capability. Miyachi et al., used spectral investigation to identify the formation of silicate in the electrodes; they attributed the better cycle life of SiO-based composites to the minimal volume change associated with the silicates during the charge/ discharge process. ${ }^{19}$ The electrode performance was further improved by the incorporation/generation of inert materials such as $\mathrm{Al}_{2} \mathrm{O}_{3},{ }^{20} \mathrm{SiO}_{2},{ }^{16,21}$ and $\mathrm{Li}_{2} \mathrm{O}^{15}$ during the preparation of the electrode material itself. Doh et al. noted the interdependency of the cycle capacity with the irreversible capacity for a dual composite using $\mathrm{SiO}$ and graphite. ${ }^{22}$ Carbon coating also provided better particle properties and conductivity for lithium ion diffusion to produce a higher cycle performance. ${ }^{20,23,24}$

This paper presents a comparative study on the electrochemical behavior of three composites prepared by ball milling of $\mathrm{SiO}$ and/or Si with graphite and one composite with carbon coating. The composites were compared using techniques such as the cycle life test, cyclic voltammetry, scanning electron microscopy, and X-ray diffraction.

\section{Experimental}

Appropriate quantities of $\mathrm{SiO}, \mathrm{Si}$ (Aldrich, -325 mesh), and graphite (Sodiff New Materials Co., Ltd, Korea, -400 mesh) were ball-milled along with stainless steel balls $(\Phi 8 \mathrm{~mm})$ at $350 \mathrm{rpm}$ for $24 \mathrm{~h}$ in a $200 \mathrm{~mL}$ stainless steel vial. The weight ratio of stainless steel balls to the material was maintained at $10: 1$, and the vial was filled with argon gas. The four weight ratio compositions considered were (a) $\mathrm{Si}: \mathrm{SiO}: \mathrm{C}=3: 1: 4$, (b) $\mathrm{Si}: \mathrm{SiO}: \mathrm{C}=2: 2: 4$, (c) $\mathrm{SiO}: \mathrm{C}=1: 1$, and (d) $\mathrm{SiO}: \mathrm{C}=1: 1$ (carbon coated). The procedure for carbon coating in the preparation of the sample (d) has been described in a previous paper. ${ }^{25}$ The prepared materials were formed into a viscous mass by mixing each composite with $15 \mathrm{wt} \%$ polyvinylidene fluoride (PVDF) dissolved in $\mathrm{N}$-methyl pyrrolidinone and agitated in a vibrator. The viscous mass was then coated onto a copper foil and dried in a hot air oven at $110^{\circ} \mathrm{C}$ for $1 \mathrm{~h}$ and pressed using a stainless 
steel roller to reduce the thickness to $\sim 75 \%$. Finally the film was annealed at $110{ }^{\circ} \mathrm{C}$ for $12 \mathrm{~h}$ in a vacuum.

The copper foil coated in active material was cut into the form of a circular disc with a diameter of $14 \mathrm{~mm}$ and coupled with a lithium foil counter electrode separated by a polypropylene separator, (Celgard membrane 2700) in a coin cell. The electrolyte (Techno Semichem. Ltd., Korea) was 1.12 M LiPF6 with 2 wt \% vinylene carbonate (VC) dissolved in ethylene carbonate (EC) and ethyl methyl carbonate (EMC) mixed in a $1: 1$ (V/V) ratio. Coin cells were assembled in a dry room maintained at $\sim 21{ }^{\circ} \mathrm{C}$ with a dew point temperature of about $-65^{\circ} \mathrm{C}$. The anode was cycled between 0 to $1.5 \mathrm{~V}$ versus $\mathrm{Li}^{+} / \mathrm{Li}$ at a constant current of $0.253 \mathrm{~mA} \mathrm{~cm}^{-2}$ ( $0.1 \mathrm{C}$ rate based on 372 $\mathrm{mAh} / \mathrm{g}$ as the specific capacity) using a charge-discharge analyzer (Toyo System Ltd, Japan).

The composite powders were examined using a Philips $1830 \mathrm{X}$-ray diffractometer with nickel-filtered $\mathrm{Cu} \mathrm{K} \alpha$ radiation at a scan rate of $0.04 \%$ s. over a 2 theta range of $10 \sim 80^{\circ}$. The surface morphology of the active material coated on the copper foil was scanned using a Hitachi S-4800 scanning electron microscope. Cyclic voltammetry was performed by cycling the electrode between 1.5 and $0 \mathrm{~V}$ at a scan rate of $0.1 \mathrm{mVs}^{-1}$; lithium foil was used as a counter/reference electrode with VSP (Princeton Applied Research Co.).

\section{Results and Discussion}

X-ray diffraction analysis. The XRD analyses of the composite samples along with individual constituents such as graphite, $\mathrm{SiO}$, and $\mathrm{Si}$ are presented in Fig. 1. The figure shows that the crystalline peaks of graphite disappeared for the ball-milled composite materials, indicating that ball-milling converted the graphite crystalline particles into finer particles in the resultant composite. Since the resultant composite did not show any new peak, it may be inferred that the ball-milling did not impact the formation of any new compounds but only fragmented the graphite into smaller particles. As the graphite particles are smaller, they should distribute evenly within the composite to provide better conductivity and cushion the effects of the composite particles by absorbing the volume expansion during the cycling process.

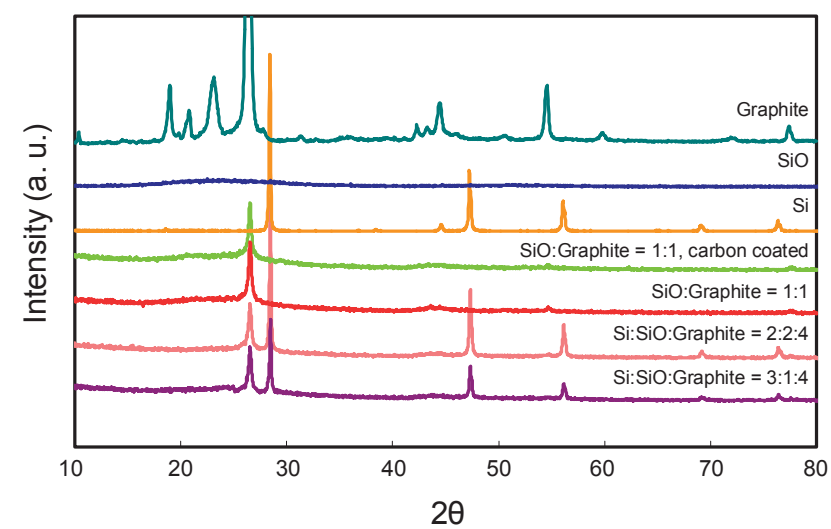

Figure 1. $\mathrm{XRD}$ pattern of materials such as graphite, $\mathrm{SiO}, \mathrm{Si}, \mathrm{SiO}: \mathrm{C}=$ $1: 1$ (carbon coated), $\mathrm{SiO}: \mathrm{C}=1: 1, \mathrm{Si}: \mathrm{SiO}: \mathrm{C}=2: 2: 4, \mathrm{Si}: \mathrm{SiO}: \mathrm{C}=3: 1: 4$.
Scanning electron micrographs. Fig. 2 presents anning electron micrographs (SEM) of the four composite electrodes. The particle aggregates in Figs. 2(a) and (b) appear to be similar, where the particles are distributed with interspaces. These interspaces act as electrolyte channels for lithium ion diffusion and also serve to absorb volume changes during lithiation and delithiation. The particle size, shown in Fig. 2(c) appears to be smaller compared to the former two. Comparision of the SEM image of sample in Fig. 2(c) with the carbon-coated sample in Fig. 2 (d) reveals that carbon coating resulted in the formation of large-sized particles along with larger interspaces relative to the samples in Figs. 2 (a)-(c).

Profile of specific capacity as a function voltage. The specific capacity-voltage behavior for the first two cycles of all composite electrodes are presented below as Figs. 3(a), (b), (c), and (d). The difference between the first lithiation and delithiation capacity values is denoted as irreversible capacity, which does not correlate to the capacity flatness property or capacity retention with cycling for the composite electrodes. To understand the exact mechanism underlying the stability of the electrode, the $\mathrm{Si}$ content present in each composite was calculated by considering the stoichiometric weight ratio $\mathrm{SiO}: \mathrm{Si}=1: 0.63$. The $\mathrm{Si}$ content in all four composites was calculated for every $4 \mathrm{~g}$ of $\mathrm{C}$ (graphite or graphite with carbon) and is presented in Table 1. The experimental data from carbon coating showed that the ratio of silicon monoxide content $\mathrm{SiO}$ : (graphite + carbon coating) of composite (d) became 4:4.036, resulting in a silicon content $\mathrm{Si}$ :(graphite + carbon coating) ratio of $2.5: 4$. The various capacity values obtained from the voltage-specific capacity curves along with the silicon content are presented for all composites in Table 1.

Capacity retention with cycling. Fig. 4 presents the specific capacity as a function of the cycle number over 50 cycles to show the capacity retention property of the four different electrodes. The maximum specific capacities for delithiation were (a) $1400 \mathrm{mAh} / \mathrm{g}$ at the fourth cycle for $\mathrm{Si}: \mathrm{SiO}: \mathrm{C}=3: 1: 4$, (b) $1450 \mathrm{mAh} / \mathrm{g}$ at the eighth cycle for $\mathrm{Si}: \mathrm{SiO}: \mathrm{C}=2: 2: 4$, (c) 870 $\mathrm{mAh} / \mathrm{g}$ at the fourth cycle for $\mathrm{SiO}: \mathrm{C}=1: 1$, and (d) $700 \mathrm{mAh} / \mathrm{g}$
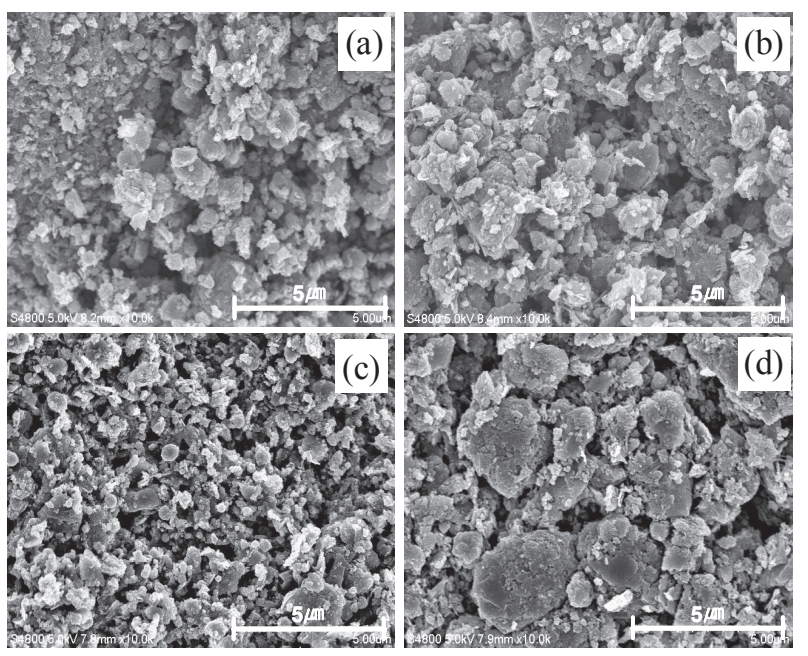

Figure 2. SEM images of the electrodes (a) $\mathrm{Si}: \mathrm{SiO}: \mathrm{C}=3: 1: 4$; (b) $\mathrm{Si}: \mathrm{SiO}: \mathrm{C}=2: 2: 4$; (c) $\mathrm{SiO}: \mathrm{C}=1: 1$; (d) $\mathrm{SiO}: \mathrm{C}=1: 1$ (carbon coated). 
Table 1. The different capacity values, capacity retention and the silicon content present in the composites

\begin{tabular}{|c|c|c|c|c|c|c|c|}
\hline \multirow{2}{*}{$\begin{array}{l}\text { Electroactive material in the } \\
\text { electrode (ratio) }\end{array}$} & $1^{\text {st }} \mathrm{LC}$ & $1^{\text {st }} \mathrm{DLC}$ & $1^{\text {st }}$ IRC & DLC ${ }_{\max } @$ cycle no. & 50th DLC & \multirow{2}{*}{$\begin{array}{l}\text { capacity } \\
\text { retention }(\%)\end{array}$} & \multirow{2}{*}{$\begin{array}{c}\mathrm{Si}: \mathrm{C} \\
\text { (gram ratio) }\end{array}$} \\
\hline & \multicolumn{5}{|c|}{$(\mathrm{mAh} / \mathrm{g})$} & & \\
\hline (a) $\mathrm{Si}: \mathrm{SiO}: \mathrm{C}=3: 1: 4$ & 1839 & 933 & 906 & 1400@4 & 480 & 34 & $3.63: 4$ \\
\hline (b) $\mathrm{Si}: \mathrm{SiO}: \mathrm{C}=2: 2: 4$ & 986 & 523 & 463 & 1450@8 & 750 & 52 & $3.27: 4$ \\
\hline (c) $\mathrm{SiO}: \mathrm{C}=1: 1$ & 1556 & 693 & 863 & 870@4 & 610 & 70 & $2.52: 4$ \\
\hline (d) $\mathrm{SiO}: \mathrm{C}=1: 1$ (carbon coating) & 1346 & 606 & 740 & 700@16 & 580 & 83 & $2.50: 4$ \\
\hline
\end{tabular}

$1^{\text {st }} \mathrm{LC}=$ first lithiation capacity; $1^{\text {st }}$ DLC $=$ first delithiation capacity; IRC = initial irreversible capacity; $D L C_{\max }=$ the maximum delithiation capacity; $50^{\text {th }} \mathrm{DLC}=50^{\text {th }}$ delithiation capacity; capacity retention $=$ capacity retention at 50 th cycle compared to $\mathrm{DLC}_{\max } ; \mathrm{Si}: \mathrm{C}$ denotes ratio of silicon and C (graphite with or without carbon coating).

(a)

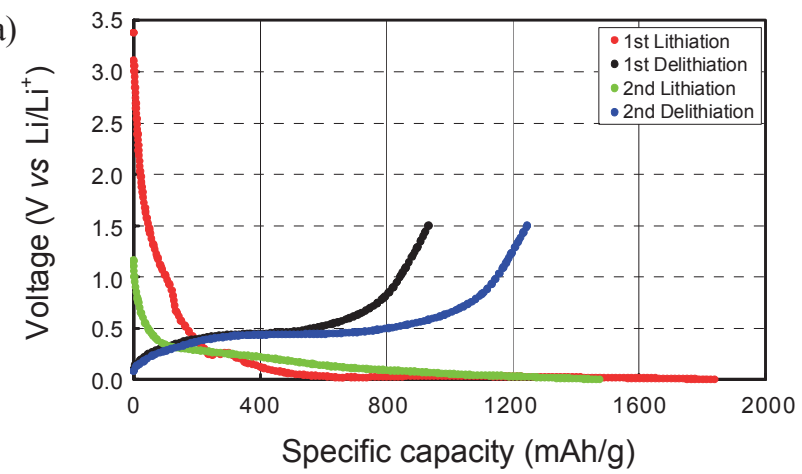

(c)

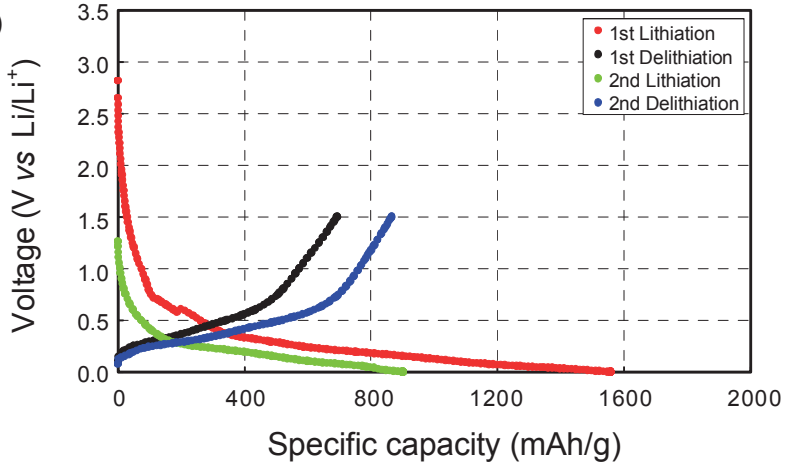

(b)

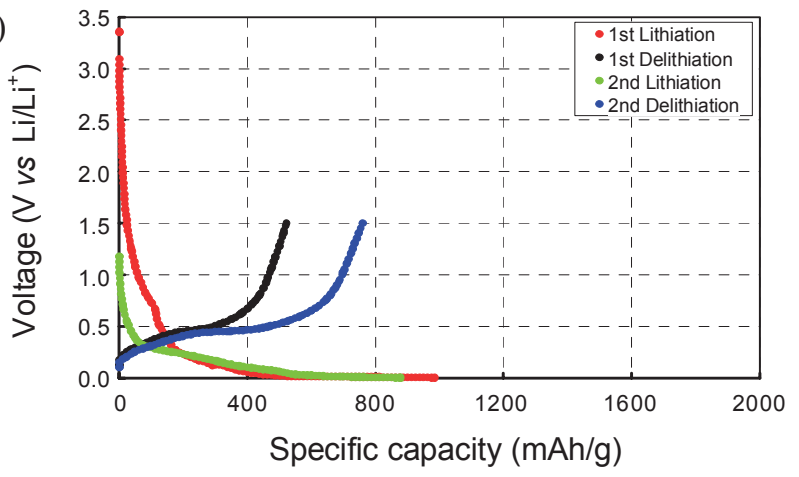

(d)

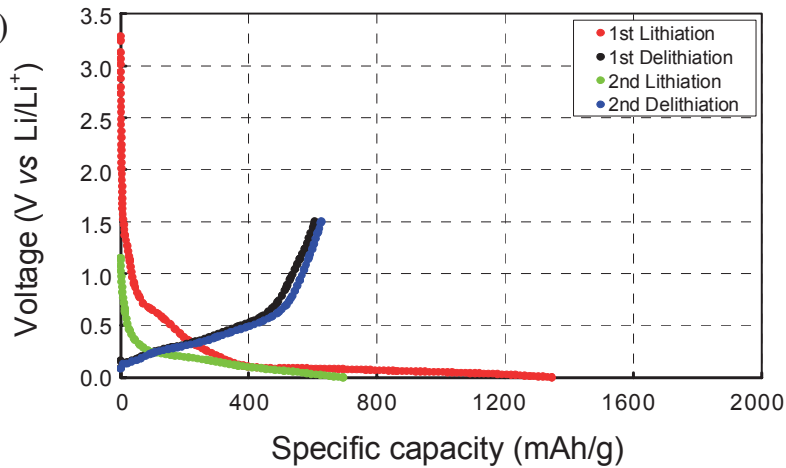

Figure 3. Voltage-Specific capacity profiles of the electrodes (a) $\mathrm{Si}: \mathrm{SiO}: \mathrm{C}=3: 1: 4$; (b) $\mathrm{Si}: \mathrm{SiO}: \mathrm{C}=2: 2: 4 ;$ (c) $\mathrm{SiO}: \mathrm{C}=1: 1 ;(d) \mathrm{SiO}: \mathrm{C}=1: 1$ (carbon coated).

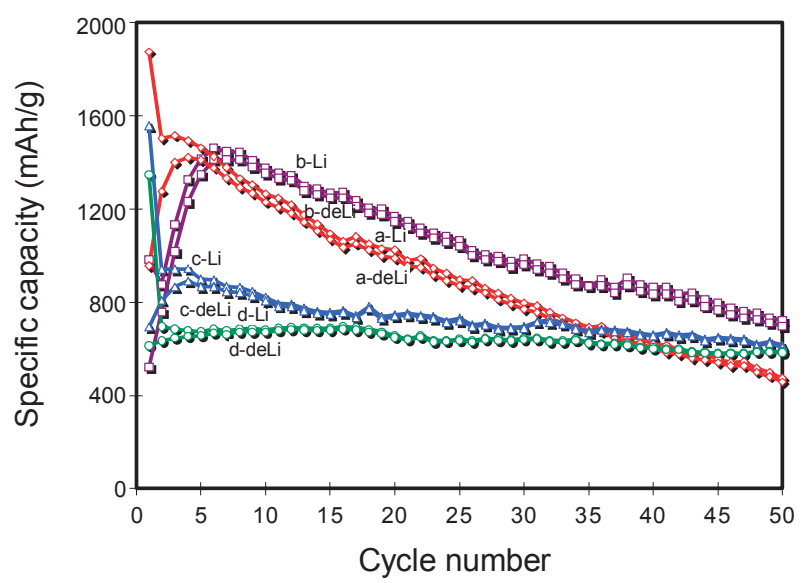

Figure 4. Profile of capacity retention with cycling: a-Li \& a-deLi, b-Li \& b-deLi, c-Li \& c-deLi, d-Li \& d-deLi are lithiation and delithiation curves for the electrodes (a) $\mathrm{Si}: \mathrm{SiO}: \mathrm{C}=3: 1: 4$; (b) $\mathrm{Si}: \mathrm{SiO}: \mathrm{C}=$ $2: 2: 4 ;$ (c) $\mathrm{SiO}: \mathrm{C}=1: 1 ;($ d) $\mathrm{SiO}: \mathrm{C}=1: 1$ (carbon coated). at the sixteenth cycle for carbon-coated $\mathrm{SiO}: \mathrm{C}=1: 1$. The specific capacities at the fiftieth cycle were (a) 480, (b) 750, (c) 610 , and (d) $580 \mathrm{mAh} / \mathrm{g}$. Therefore, the capacity retentions at the fiftieth cycle compared to the maximum specific capacity were $34 \%, 52 \%, 70 \%$, and $83 \%$ for electrodes (a), (b), (c), and (d), respectively. Fig. 4 and Table 1 show that better capacity retention with cycling is exhibited for electrodes with lower silicon content. Decreasing the silicon content in the anode composite reduces the electrode strain during the lithiation and delithiation processes. ${ }^{4,5}$ The order of the capacity retention for the composite electrodes was $(d)>(c)>(b)>(a)$. Even though the amount of carbon coating was small, its contribution to the capacity retention of the electrode was considerable; this may be due to the higher increase of conductivity because of the carbon coating. The specific capacities for delithiation were lower than for lithiation. The differences in the specific capacity for lithiation and delithiation were high when there was a high rate of decrease in capacity retention. Therefore, the difference in 


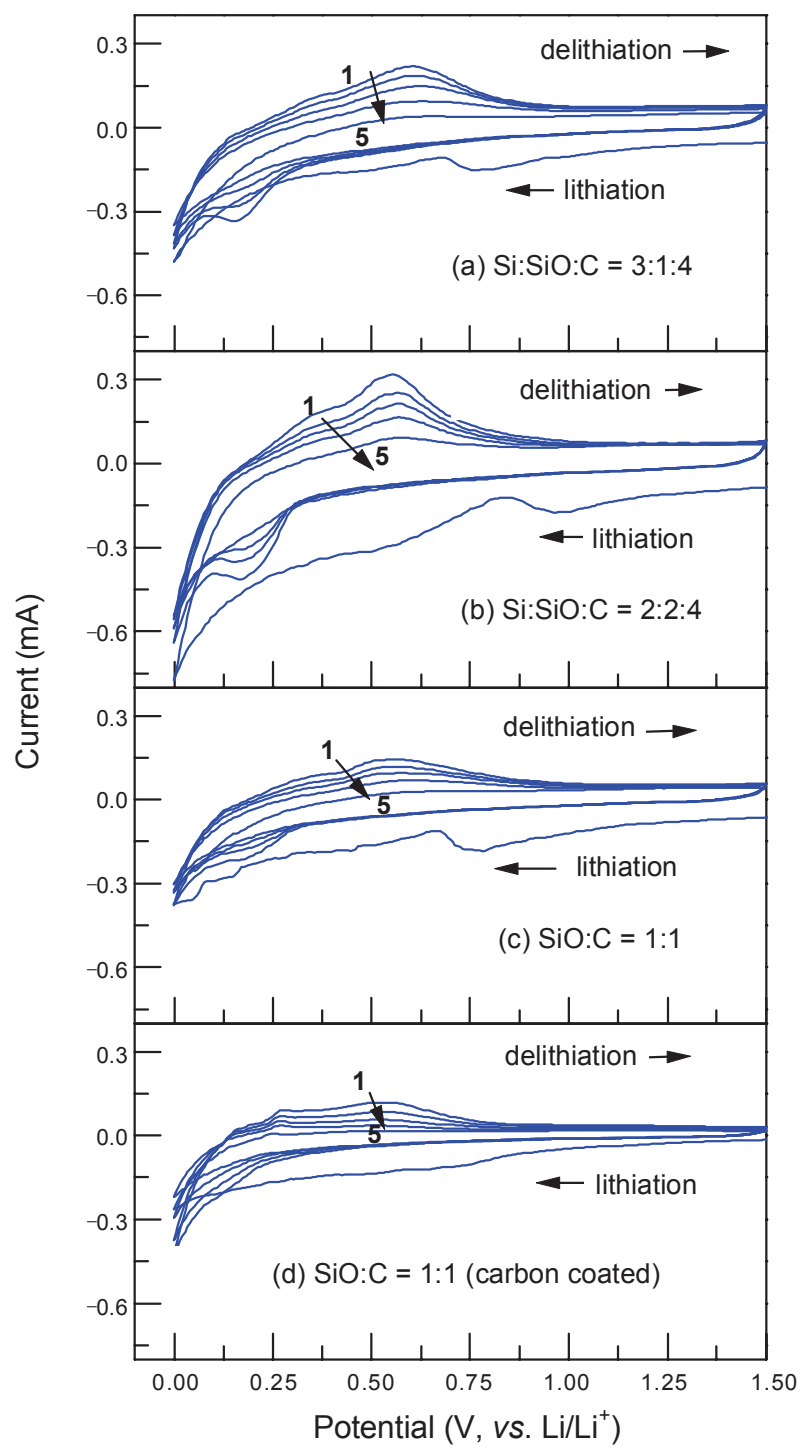

Figure 5. Cyclic voltammograms of (a) $\mathrm{Si}: \mathrm{SiO}: \mathrm{C}=3: 1: 4$; (b) $\mathrm{Si}: \mathrm{SiO}: \mathrm{C}=2: 2: 4$; (c) $\mathrm{SiO}: \mathrm{C}=1: 1$; (d) $\mathrm{SiO}: \mathrm{C}=1: 1$ (carbon coated) with scan rate of $0.1 \mathrm{mVs}^{-1}$.

specific capacities for lithiation and delithiation is correlated to the capacity retention property.

Cyclic voltammogram. The lithiation and delithiation reactions can be represented as

$$
\begin{aligned}
& \mathrm{C}_{6}(\text { graphite })+\mathrm{xLi}^{+}+\mathrm{xe}^{-} \rightleftharpoons \mathrm{Li}_{\mathrm{x}} \mathrm{C}_{6} \\
& \mathrm{xLi}^{+}+\mathrm{Si}+\mathrm{xe}^{-} \rightleftharpoons \mathrm{Li}_{\mathrm{x}} \mathrm{Si} \\
& 2 \mathrm{SiO}\left(\mathrm{Si}+\mathrm{SiO}_{2}\right)+\mathrm{xLi}^{+}+\mathrm{xe}^{-} \rightleftharpoons 2 \mathrm{Li}_{\mathrm{x}} \mathrm{SiO}\left(\mathrm{Li}_{\mathrm{x}} \mathrm{Si}+\mathrm{SiO}_{2}\right)
\end{aligned}
$$

The forward and reverse reactions associated with $\mathrm{Li}_{\mathrm{x}} \mathrm{C}_{6}(\mathrm{x}=$ 0 to 1$)$ and $\mathrm{Li}_{\mathrm{x}} \mathrm{Si}(\mathrm{x}=0$ to 4.4$)$ are pseudo-homogeneous phase reactions based on experimental results for lithiation-delithiation cycling and cyclic voltammograms which; the potential changes continuously as the value of $x$ changes. The lithiation and delithiation may occur together for graphite, silicon, and silicon monoxide. The electrodes with high drain capability have high peak current values. Such a resistive nature also implies the stability of the electrode. ${ }^{25}$ The current behaviors of (c) $\mathrm{SiO}: \mathrm{C}=1: 1$ and (d) carbon-coated $\mathrm{SiO}: \mathrm{C}=1: 1$ were similar, denoting that the full capacity appears at the given scan rate.

Commercial silicon monoxide is a two-phase material with regions rich in silicon and others rich in oxygen. The silicon-rich phase contains $\sim 1000$ - 2000 atoms, with the phase-separated regions having diameters of $3-4 \mathrm{~nm} .{ }^{26}$ The silicon-rich phase alloys and de-alloys result in volume changes of up to $\sim 328 \%$. During initial lithiation, the oxygen-rich region is converted into $\mathrm{Li}_{2} \mathrm{O}$ following reaction (4) and remains as an inert buffer material in the subsequent cycles. Other physically bonded -Opresent in the composite also forms $\mathrm{Li}_{2} \mathrm{O}$ and serves as a volume buffer during the cycling process. Lower silicon content should provide less volume change and better capacity retention to the electrodes. Furthermore, the electrolyte undergoing decomposition forms an SEI film during the initial and subsequent cycles, which may be represented as reactions (5) and (6).

$$
\begin{aligned}
& 2 \mathrm{Li}^{+}+-\mathrm{O}-+2 \mathrm{e}^{-} \rightarrow \mathrm{Li}_{2} \mathrm{O} \\
& \mathrm{Li}^{+}+(\mathrm{EC}+\mathrm{EMC} \ldots)+\mathrm{e}^{-} \rightarrow \mathrm{SEI}\left(\mathrm{Li}_{2} \mathrm{CO}_{3}, \mathrm{ROCO}_{2} \mathrm{Li}_{2} \ldots\right) \\
& \mathrm{LiPF}_{6}+2 \mathrm{xLi}^{+}+2 \mathrm{xe}^{-} \rightarrow \mathrm{LixPF}_{5-\mathrm{x}}+(\mathrm{x}+1) \mathrm{LiF}
\end{aligned}
$$

Equations (3) and (4) shows the formation of $\mathrm{Li}_{2} \mathrm{O}$, which is related to the irreversible capacity (Table 1).

\section{Conclusions}

This study reveals that the capacity degradation with cycling is high for silicon-containing composites. Of the four tested composites, the carbon-coated composite $(\mathrm{SiO}: \mathrm{C}=1: 1$ (carbon coated)) exhibited the least capacity degradation with cycling. Assuming that the capacity retention with cycling indicates the cycle stability of the anode, the capacity retention followed the order of $\mathrm{SiO}: \mathrm{C}=1: 1$ (carbon coated) $>\mathrm{SiO}: \mathrm{C}=1: 1>$ $\mathrm{Si}: \mathrm{SiO}: \mathrm{C}=2: 2: 4>\mathrm{Si}: \mathrm{SiO}: \mathrm{C}=3: 1: 4$. The silicon component in these composites followed the order of $\mathrm{SiO}: \mathrm{C}=1: 1$ (carbon coated) < $\mathrm{SiO}: \mathrm{C}=1: 1<\mathrm{Si}: \mathrm{SiO}: \mathrm{C}=2: 2: 4<\mathrm{Si}: \mathrm{SiO}: \mathrm{C}=3: 1: 4$. This shows that greater electrode stability is associated with lower Si content in the composite electrode. The carbon-coated composite has less capacity degradation with cycling, which makes it a favorable candidate for lithium ion batteries.

Acknowledgments. This work was supported by the Korea Research Council for Industrial Science \& Technology (ISTK), the NGE Program (Project No. 1001653) of KERI, and the Ministry of Knowledge Economy (MKE) of Korea. A. Veluchamy thanks the Korean Federation of Science and Technology Societies, Korea for awarding a Brain Pool Fellowship and CECRI/CSIR, India for granting leave.

\section{References}

1. Dimov, N.; Fukuda, K.; Umeno, T.; Kugino, S.; Yoshio, M. J. Power Sources 2003, 114, 88.

2. Dimov, N.; Kugino, S.; Yoshio, M. Electrochim. Acta 2003, 48, 
1579.

3. Doh, C. H.; Shin, H. M.; Kim, D. H.; Jeong, Y. D.; Moon, S. I.; Jin, B. S.; Kim, H. S.; Kim, K. W.; Oh, D. H.; Veluchamy, A. J. Alloys Compd. 2008, 461, 321.

4. Lee, J. H.; Kim W. J.; Kim, J. Y.; Lim, S. H.; Lee, S. M. J. Power Sources 2008, 176, 353.

5. Kim, Y. L.; Sun, Y. K.; Lee, S. M. Electrochim. Acta 2008, 53, 4500.

6. Doh, C. H.; Shin, H. M.; Kim, D. H.; Chung, Y. D.; Moon, S. I.; Jin, B. S.; Kim, H. S.; Kim, K. W.; Oh, D. H.; Veluchamy, A. Bull. Korean Chem. Soc. 2008, 29, 309.

7. Zuo, P.; Yin, G. J. Alloys Compd. 2006, 414, 265.

8. Wu, X. D.; Wang, Z. X.; Chen, L. Q.; Huang, X. J. Electrochem. Commun. 2003, $5,935$.

9. Patel, P.; Kim, I. S.; Kumta, P. N. Material Science and engineering $B$ 2005, 116, 347 .

10. Dong, H.; Ai, X. P.; Yang, H. X. Electrochem. Commun. 2003, 5,952 .

11. Park, M. S.; Rajendran, S.; Kang, Y. M.; Han, K. S.; Han, Y. S.; Lee, J. Y. J. Power Sources 2006, 158, 650 .

12. Jayaprakash, N.; Kalaiselvi, N.; Doh, C. H. Intermetallics 2007, 15,442 .

13. Dimov, N.; Fukuda, K.; Umeno, T.; Kugino, S.; Yoshio, M. J. Power Sources 2003, 114, 88.

14. Lee, H. Y.; Kim, Y. L.; Kong, M. K.; Lee, S. M. J. Power Sources
2005, 141, 159.

15. Yang, X.; Wen, Z.; Xu, X.; Lin, B.; Huang, S. J. Power Sources 2007, 164, 880 .

16. Zhang, T.; Gao, J.; Zhang, H. P.; Yang, L. C.; Wu, Y. P.; Wu, H. Q. Electrochem. Commun. 2007, 9, 886.

17. Kim, J. H.; Sohn, H. J.; Kim, H.; Jeong, G.; Choi, W. J. Power Sources 2007, 170, 456.

18. Poizot, P.; Laruelle, S.; Grugeon, S.; Dupont, L.; Tarascon, J. M. Nature 2000, 407, 496.

19. Miyachi, M.; Yamamoto, H.; Kawai, H.; Ohta, T.; Shirakata, M. J. Electrochem. Soc. 2005, 152(10), A2089-A2091.

20. Lee, H. Y.; Lee, S. M. Electrochem. Commun. 2004, 6, 465.

21. Kim, J. H.; Sohn, H. J.; Kim, H.; Jeong, G.; Choi, W. J. Powers Sources 2007, 170, 456.

22. Doh, C. H.; Park, C. W.; Shin, H. M.; Kim, D. H.; Chung, Y. D.; Moon, S. I.; Jin, B. S.; Kim, H. S.; Veluchamy, A. J. Power Sources 2008, 179, 367.

23. Yuan, X.; Chao, Y. J.; Ma, Z. F.; Deng, X. Electrochem. Commun. 2007, 9, 2591.

24. Chao, Y. J.; Yuan, X.; Ma, Z. F. Electrochem. Acta 2008, 53, 3468.

25. Doh, C. H.; Shin, H. M.; Kim, D. H.; Ha, Y. C.; Jin, B. S.; Kim, H. S.; Moon, S. I.; Veluchamy, A. Electrochem. Commun. 2008, 10,233 .

26. Schulmeister, K.; Madar, W. J. Non-Cryst. Solids 1975, 17, 215. 